\title{
A new subspecies of Culex (Barraudius) modestus from Japan (Diptera, Culicidae)
}

\author{
Kiyoshi KAMIMURA* and Yoshitake WADA** \\ * Toyama Institute of Hygiene and Medical Microbiology, \\ Ōtemachi, Toyama 930 \\ ** Department of Parasitology, The Institute of Medical Science, \\ The University of Tokyo, Shiroganedai, Minato-ku, Tokyo 108
}

(Received : November 16, 1973)

\begin{abstract}
While the authors were engaged in studies on mosquitoes in relation to epidemiology of Japanese encephalitis in Okayama Prefecture, western Honshu, a large number of mosquito species belonging to the subgenus Barraudius, genus Culex were collected. By comparative studies with the known species of the subgenus, the present species has been recognized most closely related to Culex (Barraudius) modestus Ficalbi, 1889; however, it differs in several morphological characters from those described by previous authors for the nominate form, especially in the structure of appendages on the subapical lobe of male genitalia. A new subspecies, Culex (Barraudius) modestus inatomii, is created, and its male, female, pupa and larva are described in this paper. The females of the present subspecies are voracious human biters. The immature stages were found in brackish water.
\end{abstract}

\section{DESCRIPTION}

\section{Culex (Barraudius) modestus inatomii} subsp. nov.

Japanese name: Inatomi-shioka

Types Holotype : o with associated larval and pupal skins, Utoma, Kojima City, June 22 , 1968, brackish swamp, Y. Wada. Allotype : $\hat{o}$ with associated larval and pupal skins and genitalia slide, same date as holotype. Paratypes: 5 우우, 6 웅, 20 larvae, all with same date as holotype. This subspecific name is dedicated to Seiiti Inatomi in recognition of his contributions to the knowledge of the mosquitoes of Okayama Prefecture. The holotype and allotype are deposited in the collection of National Science Museum, Tokyo. Part of the paratypes in the collection of British Museum (N. H.). Other types in the collection of Department of Parasitology, the Institute of Medical

* 上村 清 : 富山県衛生研究所 (富山市大乎町 1-15)

**和田芳武: 東京大学医科学研究所寄生虫研究部 （東京都港区白金台 4-6-1）
Science, the University of Tokyo.

Female (Figs. 1 and 5 A, B, C, based on 20 우 우)

Rather small-sized.

Head: Narrow decumbent scales whitish, lateral and ventral broad scales whitish, erect scales dark; proboscis 1.9-2.1 mm long, labium dark dorsally, largely pale ventrally; palpi length of about 0.15 times of that of proboscis, largely dark scaled, some pale scales on segments 3 and 4 ; length of segment 4 about 2.0 times of that of segment 3 ; antenna about as long as proboscis.

Thorax: Integument uniformly brown, pleuron lighter; mesonotal scales brown, usually lighter in front, sides, and prescutellar area ; scutellar scales light brown; $a p n$ with narrow scales and numerous (12-24) bristles ; $p p l$ and $p p n$ each with 3-6 bristles ; $p s p$ with broad whitish scales; stp with an upper and a lower patch of broad whitish scales and 5-7 bristles; pra with 6-12 bristles; mep with 2 broad scaled patches, and 1 strong dark lower and 7-10 upper bristles. 


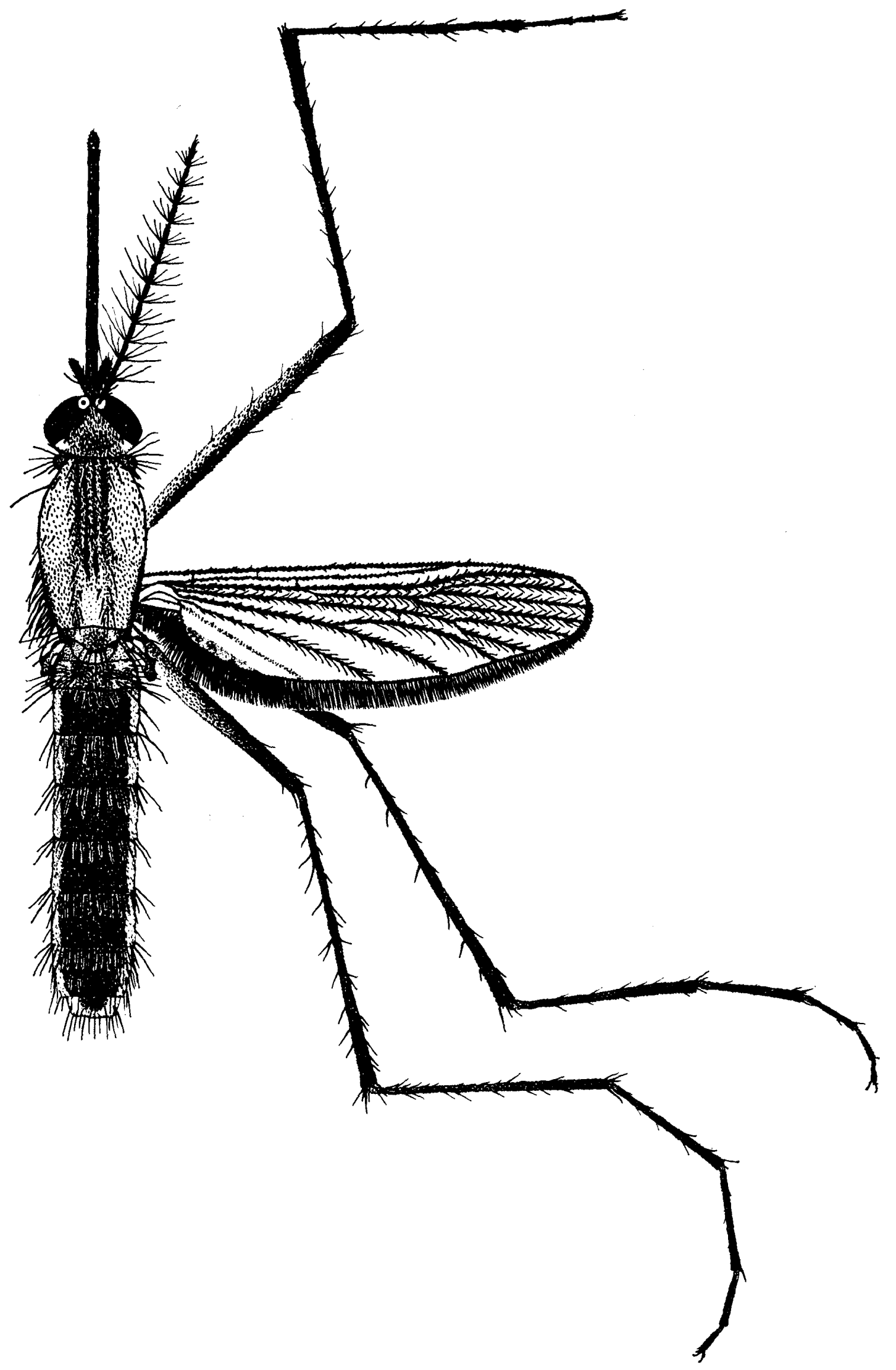

Fig. 1 C. modestus inatomii n. subsp. : female 
Legs : Coxae with light scales; forefemur 2.1-2.4 $\mathrm{mm}$ long, anterior and dorsal surfaces of femur dark, ventral and posterior surfaces and usually apex pale: tibiae predominantly dark-scaled; segment 1 of hind tarsi about 0.8 times of hind tibia in length; tarsi dark, rarely with some indistinct pale scales on all segments.

Wing: $3.0-4.1 \mathrm{~mm}$ long; stem cell ratio of $R_{2} 3.8-6.3$, that of $\mathrm{M}_{1+2} 1.5-2.0$; dorsal scales dark; halter knob pale scaled.

Abdomen: About 2.5-2.8 mm long ; tergites II-VII largely brown scaled, with pale ochreous lateral patches; first and eight tergites largely pale scaled; sternites pale ochreous scaled.

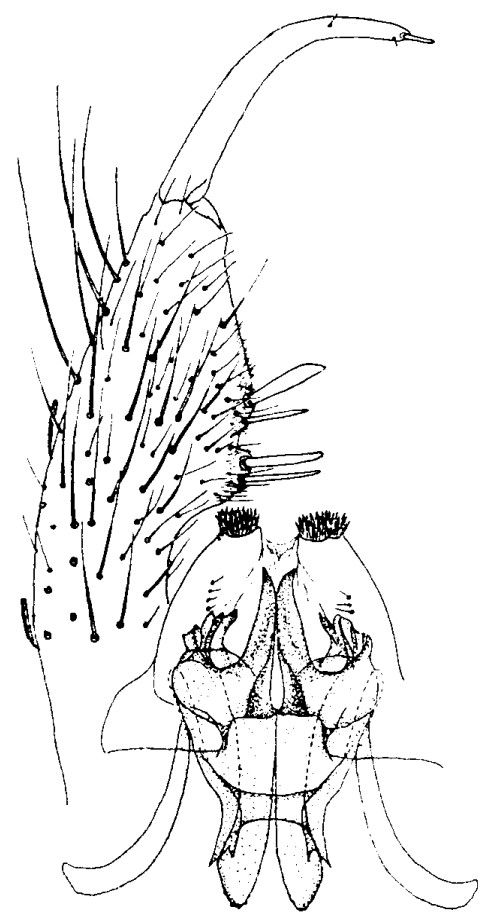

Fig. 2 C. modestus inatomii n. subsp. : male genitalia

Male (Fig. $5 \mathrm{D}$, based on 6 ô $\hat{o}$ )

Essentially as in the female; palpus exceeding proboscis usually by a little less than the lenghth of segment 5 ; wing $2.0-2.6 \mathrm{~mm}$ long; stem ratio of $R_{2} 2.2-3.0$, that of $M_{1+2}$ 1.1-2.0.

Male genitalia (Figs. 2 and 5 E, F, based on 6 genitalia slides)

Segment IX: Tergal lobe indistinct with 4-8 bristles.

Sidepiece: About three times as long as broad, with scales laterally.

Subapical Lobe: Divided into two distinct divisions each with two bladed setae; the setae subequal in length, but different in width, one on the apical division especially broadened and lanceolate.

Clasper: Slender, curved and tapered distally, a little more than half as long as sidepiece.

Phallosome: Two plates curved laterally, connected at bases, pointed apically; each plate with a short lateral arm waved along 6 of $\hat{o}$ 's lateroapical side.

Proctiger: Crowned, with 2-4 cercal setae.

Pupa (Figs. 3 and $5 \mathrm{G}$, based on 6 우 ㅇ's \& 6 of $\delta$ 's pupal skins)

Cephalothorax: All hairs moderate; hairs 1-5 usually triple $(2-4)^{*} ; 6$ quadruple $(2-5)$; 7 double (2-4);8 quadruple (3-6); 9 double or triple. Trampet: Length $0.51-0.66 \mathrm{~mm}$, width $0.14-0.16 \mathrm{~mm}$, moderately to strongly pigmented, darkened on tracheoid; tracheoid extends about 0.4 times of the overall length, pinna a little longer than 0.2 times. Metanotum: Darkened; hair 10 moderate, quadruple $(3-9) ; 11$ rather long, double ; 12 moderate, triple (2-4).

Abdomen : Length about $2.2-3.2 \mathrm{~mm}$, uniformly moderately pigmented; hair 0 minute, single on II-VIII. Hair 1 stronger, dendritic, usually $6-8$ primary branches on $\mathrm{I}$; short, multiple (4-12) on II ; long, multiple (5-11) on III ; stronger, quintuple (4-8) on IV and $\mathrm{V}$; long, 5-8 on VI ; rather long, quadruple (2-5) on VII. Hair 2 short, single on I-VII, rarely forked on I and II. Hair 3 moderate; double (1-3) on I-III ; quintuple (3-8) on IV : double (2-3) on V-VII. Hair 4 short ; quadruple (2-7) on I-III ; triple (1-4) on IV ; triple $(2-5)$ on $\mathrm{V}$ and VI ; double $(2-3)$ on VII ; moderate, double, rarely triple on VIII. Hair 5 short, 4-5 (4-8) on I ; moderate, quintuple (3-7) on II and III ; stronger, 4-5 (3-7) on IV ; stronger, barbed, double (2-3), slightly longer than the following segment on $\mathrm{V}$ and $\mathrm{VI}$ respectively; moderate, double (2-3) on VII. Hair 6 long, single, rarely forked on I and II ; moderate, double (2-4) on III ; moderate, triple $(2-5)$ on IV ; long, quadruple $(2-5)$ on $\mathrm{V}$ and VI; rather short, multiple $(5-10)$ on VII. Hair 7 moderate, double (1-3) on I and II ; short, 4-5 (3-7) on III ; short, triple or quadruple (2-6) on IV and V; rather long,

* double to quadruple. 
single on VI and VII. Hair 8 short, double or triple (1-4) on IV-VII. Hair 9 single on I-VI, sometimes forked on I rather stronger, barbed 3-6 on VII ; rather stronger, barbed, multiple (6-11) on VIII. Hair 10 rather short, single or double on III, moderate, single, sometimes double on IV and V; moderate, single on VI and VII. Hair 11 short single, sometimes forked on III-VII. Paddle: Length $0.67-0.81 \mathrm{~mm}$, width $0.55-0.61 \mathrm{~mm}$, index 1.1-1.4, uniformly lightly pigmented except for bright dark midrib; outer part rather broader than inner part; marginal spicules not developed; hair 1, 2 both present, sometimes forked or branched.

\section{Larva}

FOURTH INSTAR (Figs. 4 and $5 \mathrm{H}$, I, based on 10 larval skins and 20 larvae)

Head: Width $0.93-1.42 \mathrm{~mm}$, wider than long; mental plate with 6 or 7 teeth on each side of median tooth; preclypeal [or hair 1] spiniform, sometimes forked; outer clypeal [3] minute, simple; postclypeal [4] moderate, single ; upper frontal [5] usually triple (2-4); lower frontal [6] double or triple ; preantennal [7] multiple (5-8); frontal hairs very long, barbed, subequal ; sutural [8] quadruple (3-5), moderate; transsutural [9] moderate 5-7 (3-9) ; supraorbital [10] moderate, triple (2-4); basal [11] moderate, double, rarely triple; subbasal [12] moderate, quadruple (3-5) ; infraorbital [13] moderate, triple (2$6)$; postmaxillary [14] short, double (2-3); submental [15] multiple (5-6).

Antenna: About $0.55 \mathrm{~mm}$ long, strongly spiculated, base and distal part dark pigmented; antennal tuft [1] multiple (19-26), barbed, inserted at constriction near outer third of shaft, reaching well beyond tip; subapical and terminal hairs [2, 3 and 4] as long as tuft, single.

Prothorax: Accessory dorsal 0 moderate, tufted; shoulder hair [1-3] all single, very long; dorsal hairs [4-6] very long, single; 7 very long, triple (2-3); dorsolateral [8] double (2-3), very long; pleural group with [12] very long, single, [9] and [10] half as long, single, and [11] short, 3-5; median ventral [14] moderate, double, rarely triple. Mesothorax: Dorsals [1] moderate, single ; [2] short, triple (1-3); [3] rather long, single; [4] rather long, double $(1-4) ;[5]$,
[6] and [7] very long, single ; dorsolateral [8] very long, multiple (4-6). Pleural group with [9] a long, multiple tuft (4-6), [10] and [12] very long, single and [11] minute, single (1-4); ventrolaterals [13] and [14] rather short, tufted.

Metathorax: Dorsals [1] moderate, single, rarely double ; 2 rather short, triple (2-4); [3] moderate, triple or quadruple (3-7); [4] short, triple (2-4), [5] short, single ; [6] long, single ; [7] very long, multiple (5-13); dorsolateral [8] short, multiple (6-12); pleural group with [9]

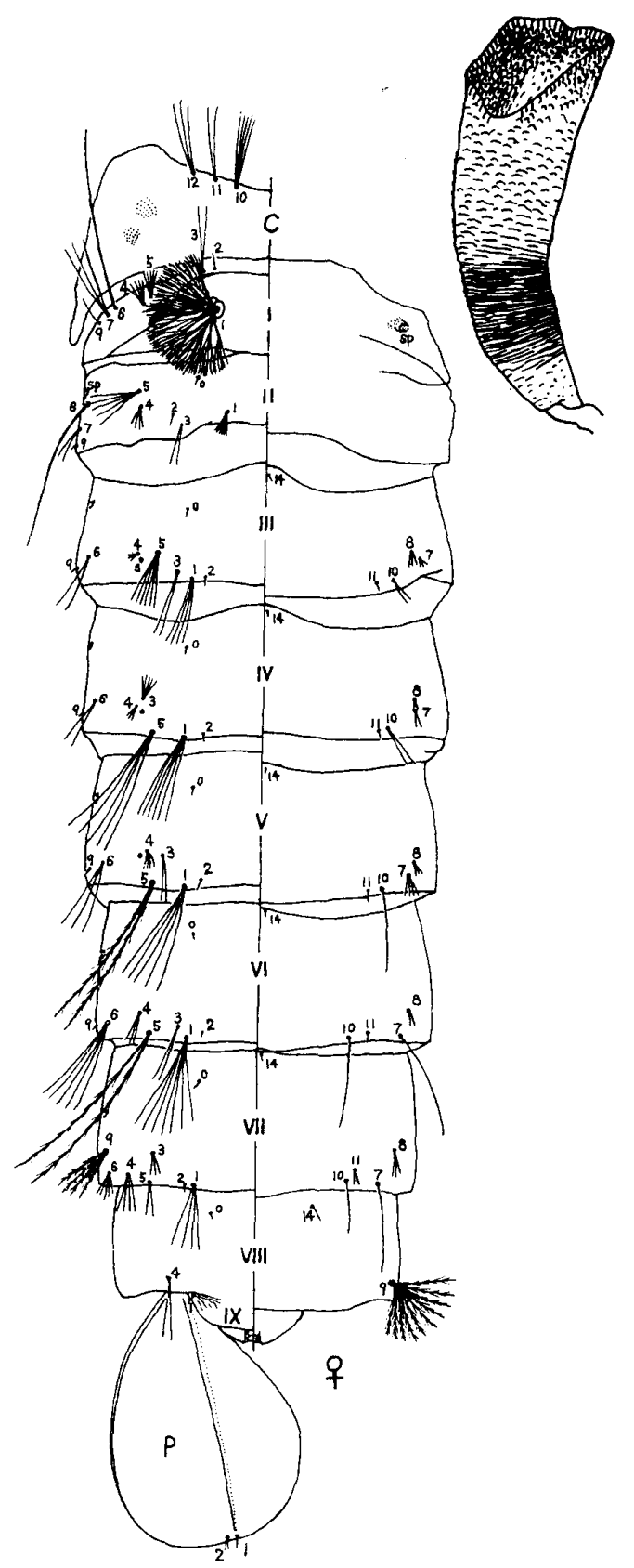

Fig. 3 C. modestus inatomii n. subsp.: pupa, Trampet (up right) and Abdomen 

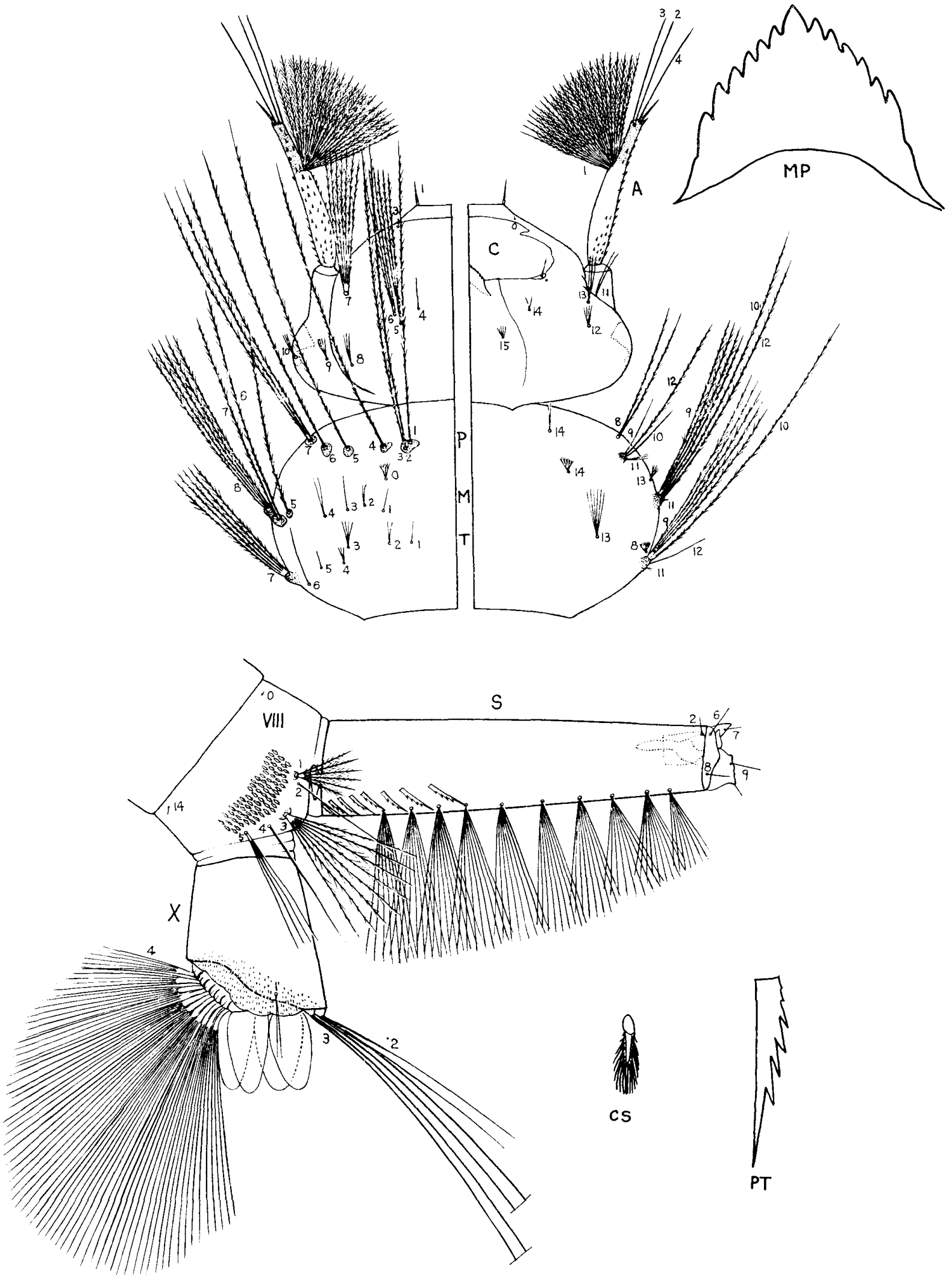

Fig. 4 C. modestus inatomii n. subsp.: head, thorax and terminal segment of larva

Fig. 5 C. modestus inatomii $\mathrm{n}$. subsp.: A, female in side view; B, femal thorax; $\mathrm{C}$, female wing; $\mathrm{D}$, male in side view; $\mathrm{E}$, male genitalia; $\mathrm{F}$, male subapical lobe; G, male pupa; H, larval head; I, larval cauda 

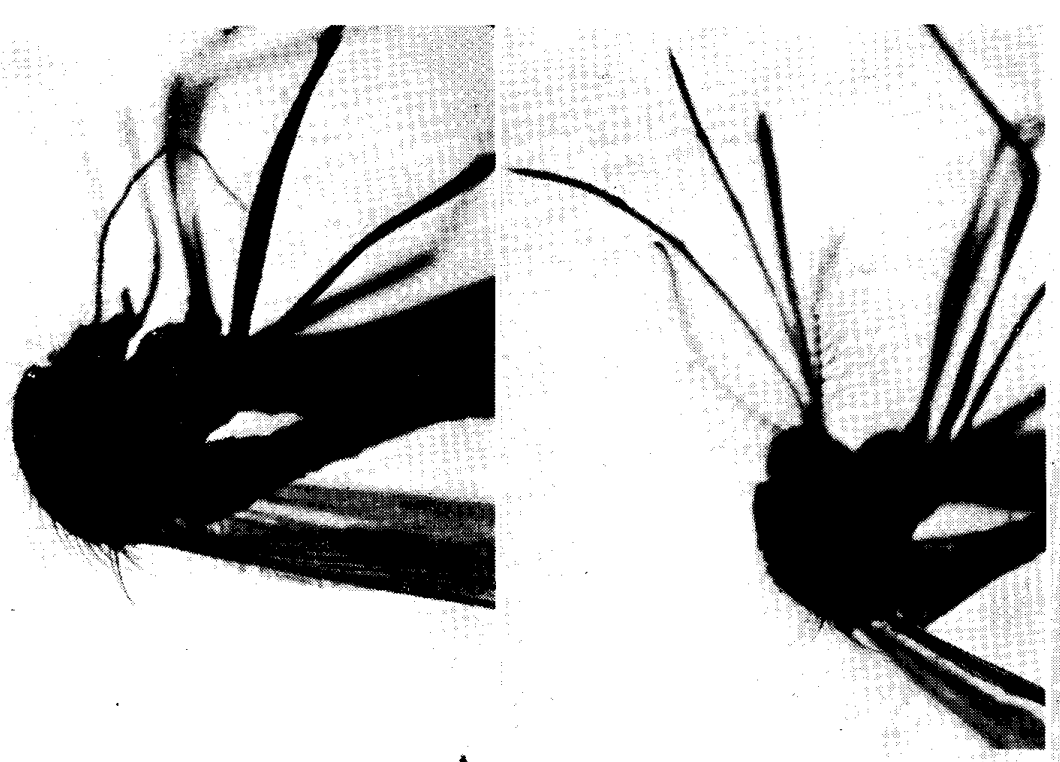

A

D
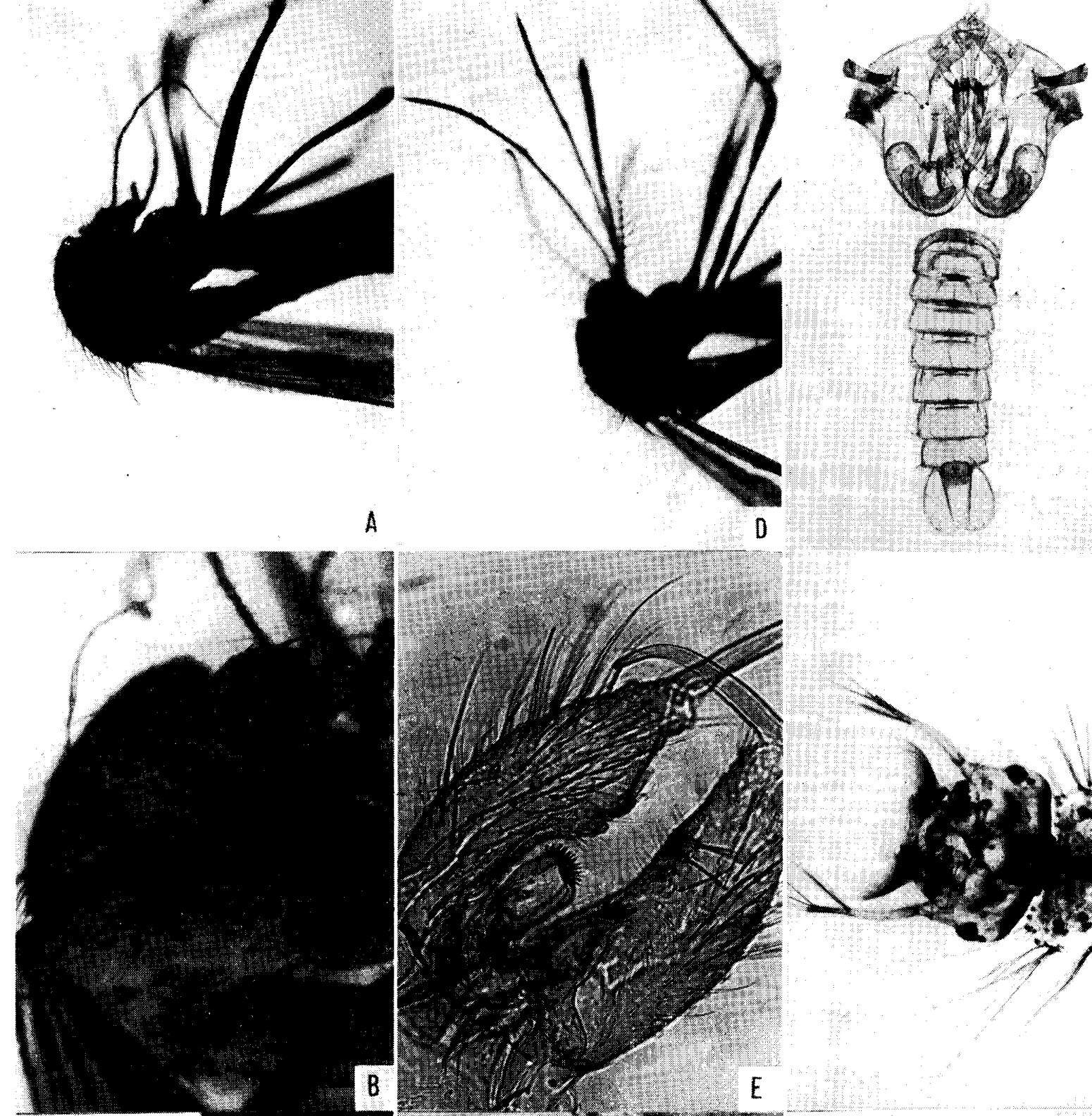

G
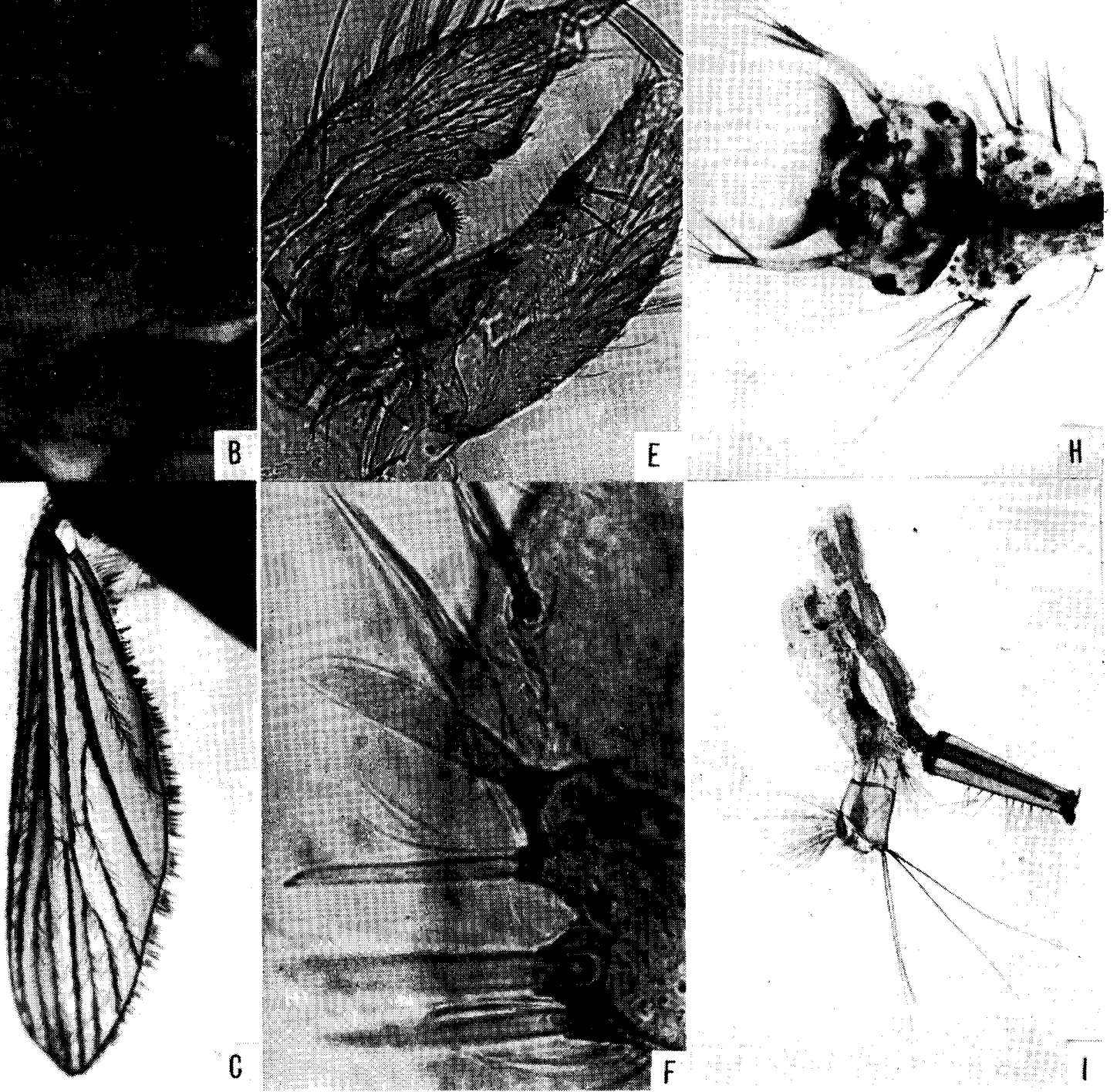

E

$H$

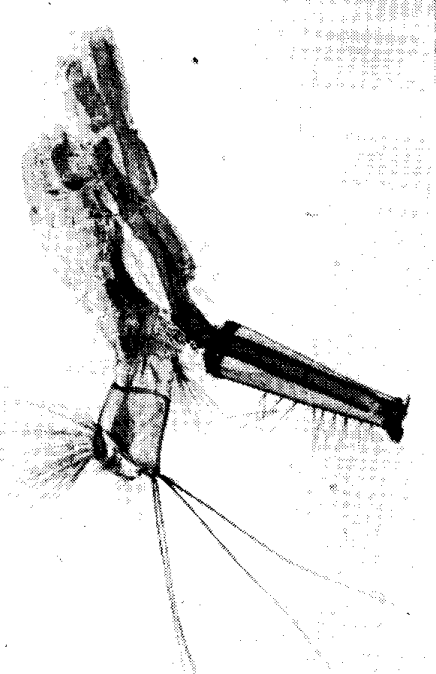


a very long multiple tuft (5-7); [10] very long, single, [12] rather long, single, rarely double, [11] short, distally double (1-3); median vent ral [13] stellate, multiple (4-9).

Abdomen : comb of segment VIII consisting of many scales (50-76) in a patch ; individual scale fringed both laterally and apically. Siphon: $0.9-1.1 \mathrm{~mm}$ long, 3 to 4 times as long as basal width, taper slightly; pecten of some teeth (8-11) on basal third; individual tooth pointed, slender, with several subequal teeth along basal two thirds of one side; siphonal tuft a single zigzag row of 10 hairs (9-12).

Anal Segment: Saddle 0.37-0.43 mm long, completely ringed; lateral hair [1] slightly shorter than the saddle, double, rarely single, with caudal fine spicules on caudal margin; gills short, bluntly rounded; upper caudal tuft [2] of dorsal brush double, rarely triple ; lower caudal tuft [3] single; ventral brush [4] usually with 6 pairs of hairs.

THIRD INSTAR (based on 4 larval skins and 3 larvae)

Head: Width 0.71-1.0 mm; upper frontal [5] double; lower frontal [6] single; preantennal [7] quadruple or quintuple; transsutural [9] triple (2-3).

Systematics: The present subspecies cannot be distinguished from the nominated subspecies modestus in the adult females. It can be separated from the latter as follows: (1) In the male genitalia, the basal division of the subapical lobe of the sidepiece bears only 2 bladed setae, and the apical division bears 1 lanceolar strong seta and 1 bladed seta, as figured; (2) In the pupa, hair 5 of segment VI rather longer than that of the following segment, and hair 9 on segment VII and also VIII with many branches; (3) In the larva, dorsal hair 4 of the prothorax is single.

Bionomics: Females were collected by routine night catches with human baits and dry-ice traps from late May to middle September in a brackish water swamp area in Fukuda and roughly one-peaked in seasonal distribution. The locality of the collection is situated about $25 \mathrm{~km}$ southwest of the City of Okayama near the coast of the Inland Sea. The females attack man and pig out of doors at night as well as in the day- time. The immature stages have been collected from brackish water swamps only.

Distribution: Honshu: Fukuda, Kurashiki City, Okayama Prefecture. Not known elsewhere. The nominated subspecies modestus has been recorded from Southern Europe, Algeria, Palestine, Iraq, Pakistan, U.S.S.R., and China (Manchuria). Two other species of this subgenus, $C$. pusillus and $C$. richeti, have been known from the Mediterranean area only.

\section{ACKNOWLEDGEMENTS}

Acknowledgements are made to Prof. Manabu Sasa, Mr. Mamoru Watanabe and others of Department of Parasitology, Institute of Medical Science, the University of Tokyo, and Prof. Seiiti Inatomi and others, staff members of Department of Parasitology, Okayama University Medical School, for their assistance in collection, and to Dr. Sadao Takagi, the Entomological Institute, Hokkaido University, for his valuable advice.

\section{REFERENCES}

Barraud, P. J. (1934) : Family Culicidae. Tribes Megarhini and Culicini. Fauna of British India, Diptera, 5 : 463 pp. Taylor and Francis, London.

Brunhes, J. and P. Venard (1966) : Contribution a l'étude des Culicidés de la région éthiopienne: description de Culex (Barraudius) richeti $\mathrm{n}$. sp.; notes complémentaires sur Culex (B.) pusillus Macquart et Culex (B.) modestus Ficalbi. Cah. O. R. S. T.O.M., sér Ent. Méd., $4(7): 75-84$.

Callot, J. and Van Ty, D. (1942-43): Localités Françaises nouvelles pour Culex (Culex) theileri, Culex (Barraudius) modestus et Culex (Neoculex) impudicus. Ann. Parasitol. hum. et comp., $19: 142-150$.

Edwards, F. W. (1921): A revision of the mosquitoes of Palaearctic region. Bull. Ent. Res., 12 : $263-351$.

Gutsevish, A. V., Monchadsky, A. S. and Stackelberg, A. A. (1970): Family Culicidae. Fauna SSSR. $7(4)$ : 384 pp. Akad. Nauk., Leningrad.

Martini, E. (1931) : Culicidae, in Lindner. Die Fliegen der palaearktischen Region, 11-12 : 398 pp. Stuttgart.

Monchadskii, A. S. (1936): The larvae of bloodsucking mosquitoes of the USSR and adjoining countries (Subfam. Culicinae). Tabl. anal. Fauna URSS, $37: 290$ pp. 
Seguy, E. (1924): Les moustiques de l'Afrique mineure, de l'Egypte et de la Syrie. Encycl. ent., 1 : 257 pp.

Senevet, G. (1947) : Le genre Culex en Afrique $\mathrm{du}$ Nord 1. Les larves. Arch. Inst. Past. d'Algérie, 25 (2) : 107-136.

Senevet, G. (1949) : Le genre Culex en Afrique du Nord 2. Les armures génitales mâles. Arch. Inst. Pasteur d'Algérie, 27 (1) : 48-65.

Senevet, G. and Andarelli, L. (1959): Les Moustiques de l'Afrique du Nord et du Bassin mediterraneen. Encycle. ent., $37: 384 \mathrm{pp}$.

Stackelberg, A. A. (1937) : Fam. Culicidae (Subfam. Culicinae). Faunede l'URSS. Insectes, Dipteres, $3(4): 257$ pp.

Theobald, F. V. (1904): A monograph of the Culicidae, 3 : 359 pp. Brit. Mus. (Nat. Hist.), London.

Wada, Y., Kamimura, K. and Sasa, M. (1968): Newly record mosquito of subgenus Barraudius from Japan. Jap. J. Sanit. Zool., 19(2) : 120.
摘

本邦産 Culex (Barraudius) modestus $の$

一新亜種について

1967，68年の 5 月から 9 月にかけて，岡山県倉敷市福 田干拓地から，シオ力带属 Barraudius に属する蚊を 採集し, Culex modestus の一新亜種 inatomii イナト ミシオカとして, 雌成虫, 雄成虫と外部生殖器, 蛹, 4 令および 3 令幼虫の記載を行なった. 雌成虫は一見, 鱗 毛の脱落したアカイエカに近似して，やや小形である. 基亜種とは雄外部生殖器側片の亜先端葉の剛秏の形態に 差異が明らかで，蛹の第 6 腹節 5 毛が第 7 腹節よりも若 干長く，第 $7 ， 8$ 部節の 9 毛は多岐し，幼虫の前胸 4 毛 は単条である。雄成虫は昼，夜間，野外で人や豚を吸 血し，ドライアイスで誘引捕集される. 幼虫は付近の塩 性湿原からのみ発見された。 